DOI: https://doi.org/10.32839/2304-5809/2021-11-99-43

УДК 7:37+17:37.034

Хохлов А.С.

Східноукраїнський національний університет імені Володимира Даля

\title{
ХУДОЖНЬО-ЕСТЕТИЧНЕ НАВЧАННЯ - ДЖЕРЕЛО ЕНЕРГІЇ МОРАЛЬНОГО ХАРАКТЕРУ
}

\begin{abstract}
Анотація. Як сонячна енергія забезпечує життя на планеті, так художньо-естетичне навчання $є$ джерелом духовного й морального на Землі. Стаття присвячена дослідженню сутності та значимості художньоестетичного навчання в контексті формування та розвитку особистості учня, його морального характеру, емоційно-ціннісної системи. Наведено приклади й докази переваги високоморального й суспільно орієнтованого навчання перед навчанням як системи знань, умінь і навичок. У статті наголошуеться, що постійно зростаючий рівень глобалізаційних процесів та їхній вплив на пріоритети кожної людини, суспільства та світу призводить до занепаду стійких культурних, громадянських, духовних, моральних проявів й орієнтирів особистості. Розглянуто й аналізовано поняття «ентелехія» як першомотиву і внутрішньої стимулюючої енергії давньогрецького науковця Арістотеля; «енергії морального характеру» Гербарта, яке німецький педагог, психолог і філософ визначає ціллю морального навчання й виховання. Ентелехія i енергія можуть бути розглянуті єдино як вмотивована рушійна сила внутрішньої моралі. Продемонстровано зв'язок ціеї енергії із навчанням засобами мистецтва, її значення у всебічному, творчому та моральному розвитку особистості учня, яка має розглядатися як фундаментальна складова суспільства. Визначено, що художньо-естетична освіта у сучасному світі з урахуванням світових вимог і тенденцій несе і має нести ключове значення у формуванні морального характеру учня.
\end{abstract}

Ключові слова: мистецтво, навчання, естетика, моральність, характер.

Khokhlov Artem

Volodymyr Dahl East Ukrainian National University

\section{ART-AESTHETIC EDUCATION - A SOURCE OF ENERGY OF A MORAL CHARACTER}

Summary. As sun energy provides life on a planet, so art-aesthetic education functions as a source of all spiritual and moral on the Earth. The article is devoted to the study of the essence and significance of art and aesthetic education in the context of the formation and development of the pupil's personality, its moral character, emotional and value system, in particular the harmony between knowledge and judgments, personal will and desire to better, good. It is emphasized that art-aesthetic education is capable of contributing to the pupil's understanding of the importance of moral, cultural value of sustainable development of each member of society. Aesthetic consciousness is a source for the disclosure of creative and spiritual abilities of the pupil, a source that promotes support and constant vigorous stimulation of something creative, aesthetic, moral. Examples and evidence of the advantage of high-molar and socially oriented education over studying as a system of knowledge and skills, because a highly educated, and the moral valued person can be considered successful, can improve its personally and culture, society, the world as a whole. The article emphasizes that the ever-growing level of globalization processes and their influence on the priorities of each person, society and the world leads to a declination in sustainable cultural, civil, spiritual, moral manifestations and focuses, promoting the higher stage of economic, political, technological advantages, achievements. The concept of "entelechia" as a primary and internal stimulating energy of the ancient Greek scientist Aristotle is considered; "energy of moral character" is determined by Herbart, German teacher, psychologist and philosopher, as the purpose of moral education and upbringing. Entelechy and energy can be considered together as motivating-driving force of internal morality. The connection of this energy with art education, its significance in the comprehensive, creative and moral development of the pupil's personality, which should be considered as a fundamental component of society, is demonstrated. Representations of the world are formed with art forms, and then the soul is established not by the laws of being, but with practical reflection. It is determined that art and aesthetic education in the modern world, taking into account the world requirements and trends, bears and has a key importance in creation the moral pupil's character.

Keywords: art, education, aesthetics, morality, character.

$\Pi$ остановка проблеми. Багато цілей, поставлених перед собою сучасним світом, передусім грунтуються на загальному економічному зростанні, розвитку, не уникаючи процесів інформатизації та цифровізації всіх сфер діяльності людини. Економічні, політичні, суспільногромадські, екологічні, технологічні та діджиталізаційні глобальні ефекти й впливи безумовно сприяють реформації та розвитку суспільства, цілого світу. Є зрозумілим, але потребуе наголосу те, що основною ланкою, «фундаментальним атомом» будь-яких процесів та формувань у світі постае саме особистість, особистість-носій культу- ри і моральності, яка повинна ціннісно та активно брати участь у розвитку суспільства.

Аналіз останніх досліджень i публікацій. Питання художньо-естетичної освіти, проблеми, пов'язані із мораллю, роллю мистецтва у формуванні особистості, цінностей та розвитку естетичної свідомості представлені у працях та розглядаються вітчизняними та зарубіжними науковцями з давніх давен та у сучасності від Платона, Арістотеля до Д.С. Соммера. Г.С. Кнабе, Ю.М. Вільчинського, Ф. Шиллера, І. Канта, А. Дістервега, К.Д. Ушинського, П.М. Якобсона, В.О. Сухомлинського, Й.Ф. Гербарта, Ф. Гегеля, 
В.О. Лозового, С. Фартінга, Е. Вагнера, Г.П. Шевченко, Рудковської І.В.

Виділення не вирішених раніше частин загальної проблеми. Досліджуючи поняття зазначенної теми і поставленної проблеми, яким присвячуеться стаття, стае зрозумілим, що багато науковців і фрахівців в області художньо-естетичної освіти спираються на значущість мистецького навчання у формуванні всебічної особистості учня, його естетично-культурної та моральноціннісної свідомості, уникаючи при цьому наголосу на силу, енергію, потенцію і майбутне ціеі свідомості та характеру. Сутність вказаних не вирішених проблем має бути розглянута, адже засобами художньо-естетичної навчання мае формуватися саме сталий і стійкий, високоморальний характер учнів, які будуть бажати та діяти в інтересах кращих змін суспільства та світу.

Мета статті - дослідити та встановити значимість художньо-естетичного навчання у формуванні й розвитку енергійного, стійкого морального характеру особистості учня.

Виклад основного матеріалу. Сучасний стан освіти потребуе сформовану особистість учня, який був б успішним, яка повинна «мати зовнішній (соціальний) або внутрішній (особистісний) прояв. Підготовка успішної людини передбачає формування такої особистості, яка, одночасно, може залишатися вірною власним внутрішнім установкам і цінностям, тобто проявляти внутрішню (екзистенціальну) успішність та бути адаптованою до вимог суспільства (проявляти соціальну успішність). Постає питання формування необхідних компетенції, навичок, які б сприяли цьому процесу. Тому виникае питання яку роль в підготовці успішної людини виконуе освіта» [6, с. 206]. У своїй праці Козьменко О.I. вказуе також та те, що освіта не лише повинна надавати знання, розвивати навички й вміння, але й сприяти формування людини, вихованню iї духовно-культурних цінностей та ставлення до себе й світу [6, с. 206-207].

Досліджуючи погляди німецьких науковців, зокрема Канта, Дістервега й Шиллера щодо естетичного навчання та «моральні» погляди чилійського фрілософра Д. Соммера, можна припускати або (не)стверджувати, що «ми просто «цивілізовані дикуни» або грайливі діти. Досягнення науки та технологій дають нам оманливе відчуття могутності. Це знижуе здатність людини до самокритики та не дозволяе їй побачити, що між їі уявленням про цивілізоване людство й людством $\epsilon$ величезна прірва. В цьому жорстокому світі не припиняються війни та конфлікти, в різних куточках планети люди щодня гинуть від голоду та насилля» $[10$, с. 30]. Думки філософо пояснюються тим і вказують на те, що в умовах сучасності людина втрачае людські якості, емоційно та естетично бідніє. Саме моральні, громадянські, естетичні та духовно-ціннісні орієнтири й прагнення, як складові художньо-естетичного навчання, здатні сприяти насправді успішному зростанню суспільства, людства.

Представляючи «портрет сучасної освіти без прикрас», Саух П.Ю. підкреслюе, що «основною метою, що постає перед національними освітніми системами, е підготовка індивіда, який володіє достатніми знаннями і можливостями для своеї діяльності в різноманітних культурно-політичних контекстах» $[9$, с. 20]. В противагу та із більшою значимістю виступають концептуальні позиції художньо-естетичної освіти, які переміщуються від погляду на мистецтво до погляду на світ, від розуміння мистецтва до розуміння світу. Художньо-естетична освіта - це не лише процес творчої діяльності, навчання різним видам мистецтва, формування навичок їх розуміння, але й також розкриття творчих потенціалів учня, самоактуалізація його особистості, розвиток гуманістичних, культурних, естетичних і моральних цінностей. В працях сучасних вчених можна знайти підтвердження вищезазначеного, зокрема Барвіна Н.О. вказуе, що «розвинена естетична свідомість та її реалізація через естетичну діяльність $є$ основними індикаторами естетичної культури особистості, виховання якої засобами мистецтва включає в себе, насамперед, формування естетичної свідомості, що відбувається в процесі знайомства 3 культурною спадщиною, засвоєння духовного досвіду, що був накопичений століттями, їхній аналіз та осмислення, особисті естетичні почуття, що з'являються в результаті, а також розвиток художньо-творчих здібностей та навичок, що знаходять імплементацію через художньо-естетичну діяльність» $[1$, с. $10-11]$. Hiмецький педагог Гюнтер Отто тісно пов'язуе естетичне навчання із розумінням та переживанням соціальної реальності, адже будь-яка людина повинна бути активним учасником суспільних процесів [11, с. 3]. Слід наголосити, що саме естетично свідома, високоосвічена та високоморальна особистість, яка прагне до постійного розвитку й вдосконалення, здатна поширювати ці тенденції серед інших.

Заняття музикою, наприклад, в класі, групі зміцнюе почуття спільності, тому що учні можуть разом відкривати звуки і ритми, вводити свої власні теми і відкривати музику по-своєму; чуттевим і фрізичним видом мистецтва є танець, який відкривае красу рухів тіла та проявів душі. Але незалежно від областей мистецтва (чи живопис, скульптура, графріка, прикладне мистецтво, література, музика, хореографія, театр, архітектура), яким навчають, креативні та інтерактивні моделі уроків і інших заходів спрямовані передусім на розвиток творчої особистості з урахуванням необхідності знань-пізнання та взаємоповаги до думок кожного. Художня робота надае учням можливість і свободу випробувати нові підходи. Експериментальний підхід робить можливою появу непередбачуваного результату. Якщо процес конструктивно супроводжуеться викладачами і фахівцями в області мистецтва і культури, щоб бажання і мотивація не пропали, мистецтво може посилити в учнях радість експериментування і сприяти розвитку здатності інноваційно вирішувати проблеми і знаходити результати, надихнутися наявними матеріалами, реалізувати власні ідеї, спробувати нову техніку і подивитися на створені роботи, встановлюючи зв'язки із дійсністю.

До понять сили та енергії, першопочатку, стимулу й внутрішньої рухомої сили звертався давньогрецький науковець Арістотель, поєднуючи зазначені смисли в «ентелехії» [8, с. 122]. Естетично свідома та високоморальна особистість не 
повинна розумітися як результат навчання й виховання. Акцентованою має бути необхідність постійного потенціалу, потенції та енергії цієї особистості, як «носія-транслятора» моральних цінностей. Так, ентелехія і енергія можуть бути розглянуті єдино як вмотивована рушійна сила внутрішньої моралі. Навчання засобами мистецтва, враховуючи його зміст, цілі, методи і dpopми, здатне у єдності із вихованням розвинути моральний характер особистості учня, як необхідної основи суспільства. Художньо-естетичне навчання, маючи вплив на думки, внутрішній світ учня, його емоції, має розглядатися джерелом сил та енергії для естетичного, культурного й морального становлення та подальшого розвитку особистості учня. Як процес освіти в подальшому проявляеться в результаті, так і процес становлення морального в учні має на увазі закріплення цього процесу. Німецький педагог, психолог, фрілософ Иоганн Фрідріх Гербарт виділив, що недостатньо, якщо ця моральність не є стійкою; погано також, якщо щось неморальне стає постійним. Для уникнення та взаємовиключення цих понять педагог окреслюе мету морального навчання - енергія морального характеру. Певна фрорма волі, яку називають характером, базуеться не лише на хотінні (бажанні), але й на нехотінні (небажанні). Нехотіння, як відсутність бажання, прагнення здійснити що-небудь, також є проявом внутрішніх прагнень особистості [3, с. 200-204]. Не дивлячись на те, що Гербарт И. проявляв свою активну науково-практичну діяльність у XVIII-XIX-х століттях, його погляди заслуговують уваги, виходячи 3 їхньої сьогоденної актуальності. Тим паче, стійкість морального характеру проявляеться в стійкості його енергії та добрих прагнень в майбутньому після невдач та переживань у минулому. 3 одного боку, дитина, потрапивши до біди або маючи негативний зовнішній вплив, а також отримуючи нові уявлення про світ може змінитися сама, модифікуючи свої відношення до дійсності, похитнути свої моральні стійкості, настанови й цінності, які були виховані в неї при культурних і моральних орієнтирах художньо-естетичної освіти. Все ж таки, з іншого боку, художньо-естетичне навчання тісно пов'язане із емоційно-ціннісною сфрерою особистості, для якої «фундамент, кріпкі стіни для майбутнього будівництва та оздоблення» були возведені у творчому процесі навчання мистецтв. Гербарт Й. у листах про естетичне уявлення світу вказує, на те, що це є головною складовою виховання. Моральність виступає як найвища ціль виховання, але в умовах реальних можливостей. Виховання характеру закладається в тому, аби учень (вихованець) зміг знайти себе, шукаючи добро та заперечуючи зло у реально переживаних ситуаціях. Цей зріст до самосвідомої особистості має пройти через душу вихованця й здійснитися за допомогою його особистої діяльності. Науковець також звертається до вихователів, стверджуючи, що в кожній дитині необхідно знайти його внутрішну силу, зрозуміти її, сприяти її розвитку, руху [3, с. 351-352].

Розвиток, формування стійкості та гнучкості емоційно-ціннісної сфрери особистості учня повинні також стояти на чолі кута в системі міждисциплінарної освіти. Це пояснюеться тим, що разом із формуванням естетичного і морального в учневі пріоритетними $є$ і заслуговують уваги також його почуття, особистісні відношення. Науковий співробітник Інституту педагогіки НАПН України Вашуленко О. в своїй праці вказує: «Під емоційно-ціннісним розвитком ми розуміемо цілеспрямоване фрормування в учнів системи значущих для особистості і суспільства ціннісних орієнтацій, розвиток їхньої емоційнопочуттевої сорери. Відомо, що емоційно-ціннісний розвиток особистості здійснюеться протягом усього періоду навчання в школі, але саме в початкових класах закладаються основи ціннісних орієнтацій, вольового розвитку і проявляеться особлива сенситивність до емоційного розвитку. 3 огляду на це проблема розвитку емоційної і почуттєвої сфрери молодших школярів, умінь висловлювати оцінні судження, своє ставлення до себе, інших, світу, умінь правильно оцінювати свої вчинки та вчинки інших, прищеплення загальнолюдських i національних цінностей $є$ досить актуальною» [2, с. 2-3].

Висновки та пропозиції. Таким чином, дослідивши джерела інформащії, можна визначити, що художньо-естетичне навчання відіграе дуже важливу роль у формуванні особистості учня, його поглядів та оцінок дійсності, морального характеру. Думки Й. Гербарта щодо стійкості морального характеру потребують подальших досліджень, адже в системі мистецької освіти залишається дуже важливим усвідомлення того, що морально-ціннісний характер й естетична свідомість мають бути непохитними, незалежно від негативних впливів неморального, бути завжди енергійними, живлячись від мистецтва, морально доброго заради майбутнього світу.

\section{Список літератури:}

1. Барвіна Н.О. Культурно-виховна місія мистецтва в університетській театральній студіі. Духовність особистості: методологія, теорія і практика. 2020. Том 95. № 2. С. 6-17.

2. Вашуленко О.В. Емоційно-ціннісна складова у структурі читацької компетентності молодшого школяра. Початкова школа. 2013. № 1. С. 13-17.

3. Главнейшие педагогические сочинения Иог. Гербарта в систематическом извлечении: с очерком жизни и деятельности Гербарта / Пер. с нем. А. В. Адольфа. Москва : К. Тихомиров, 1906. XV, с., [1] л. портр.; (Педагогическая библиотека, издаваемая К. Тихомировым и А. Адольфом. Вып. 14). 365 с.

4. Дистервег А. Избранные педагогические сочинения. Москва : Учпедгиз, 1956. 378 с.

5. Кант I. Естетика / Пер. 3 нім. Б. Гавришкова. Львів : Аверс, 2007. 360 с.

6. Козьменко O.I. Значущість освіти у підготовці успішної людини. Lublin, the Republic of Poland. International scientific and practical conference. September 25-26, 2020, "Baltija Publishing". P. 205-208.

7. Крушельницька Я.В. Фізіологія і психологія праці : Навч. посібник. Київ : КНЕУ, 2000. 232 с.

8. Лосев А.Ф. История античной эстетики. Аристотель и поздняя классика / Худож.-офор. Б.Ф. Бублик. Харьков : Фолио; Москва : ООО «Издательство АСТ», 2000. 880 с. (Вершины человеческой мысли).

9. Саух П.Ю. Сучасна освіта: портрет без прикрас : монографія. Житомир : Вид-во ЖДУ ім. І. Франка, 2012.382 с. 
10. Соммер Д.С. Мораль ХХІ века. Москва : Кодекс, 2014. 480 с.

11. Draxl, Edith; Fischer, Andrea. Die Welt ein wenig zugänglicher machen. Ästhetische Bildungsprozesse und Differenzerfahrung im Kunstlabor Graz. Magazin erwachsenenbildung.at (2014) 22, 11 p.

\section{References:}

1. Barvina N.O. (2020) Kulturno-vykhovna misiia mystetstva v universytetskii teatralnii studii [Cultural and educational mission of art at the university drama studio]. Spirituality of personality : methodology, theory and practice, no. 95, vol. 2, pp. 6-17.

2. Vashulenko O.V. (2013) Emotsiino-tsinnisna skladova u strukturi chytatskoi kompetentnosti molodshoho shkoliara [Emotionally-valued constituent in the structure of reader competence of junior pupil]. Primary school, no. 1 , pp. 13-17.

3. Glavnejshie pedagogicheskie sochinenija Iog. Gerbarta v sistematicheskom izvlechenii: s ocherkom zhizni i dejatel'nosti Gerbarta / Per. s nem. A. V. Adol'fa (1906) [The most important pedagogical compositions of Johann Friedrich Herbart in systematic extraction: with the essay of life and activity of Herbart. Translated by A. V. Adol'f]. Pedagogical library, no. 14, 365 p.

4. Disterveg A. (1956) Izbrannye pedagogicheskie sochinenija [Selected pedagogical compositions]. Moscow: Uchpedgiz, $378 \mathrm{p}$.

5. Kant I. (2007). Estetyka / Per. z nim. B. Havryshkova [Aesthetics / Translated by B. Havryshkova]. Lviv: Avers, 360 p.

6. Kozmenko O.I. (2020) Znachushchist osvity u pidhotovtsi uspishnoi liudyny. [Significancy of education in preparation of a successful individual]. Lublin, the Republic of Poland. International scientific and practical conference September 25-26, 2020. Baltija Publishing, pp. 205-208.

7. Krushelnytska Ya.V. (2000) Fiziolohiia i psykholohiia pratsi. [Physiology and psychology of work]. Kyiv: KNEU, 232 p.

8. Losev A.F. (2000) Istorija antichnoj jestetiki. Aristotel' i pozdnjaja klassika. [History of ancient aesthetics. Aristotle and the late classics]. Har'kov: Folio; Moscow: Izdatel'stvo ACT, 880 p.

9. Saukh P.Yu. (2012) Suchasna osvita: portret bez prykras [Modern education: unvarnished portrait]. Zhytomyr: ZhDU I. Franka, 382 p.

10. Sommer D.S. (2014) Moral' XXI veka [Morality of the 21st century]. Moscow: Kodeks, 480 p.

11. Draxl Edith, Fischer Andrea (2014) Die Welt ein wenig zugänglicher machen. Ästhetische Bildungsprozesse und Differenzerfahrung im Kunstlabor Graz (germ.). Magazin erwachsenenbildung.at. $11 \mathrm{p}$. 